Ciência e Natura, Santa Maria, v. 37 n. 3 esp. 2015, p. 58-69

Revista do Centro de Ciências Naturais e Exatas - UFSM

ISSN impressa: 0100-8307 ISSN on-line: 2179-460X

\title{
ciênciaenatura
}

\section{Analysis of relationships between Intellectual Capital and measurement performance indicators of the pharmaceutical companies in Tehran Stock Exchange}

\author{
Hadi Kord Javadi ${ }^{1}$, Zahra Kohandel ${ }^{2}$, Khadije Fardi ${ }^{3}$
}

${ }^{1}$ Young Researchers and Elite Club Torbat-e-Heydarieh Branch, Islamic Azad University, Torbat-e-Heydarieh, Iran

${ }^{2} \mathrm{Al}$-Zahra University Branch. Tehran

${ }^{3}$ Young Researchers and Elite Club Behbahan Branch, Islamic Azad University, Behbahan, Iran

\begin{abstract}
Intellectual Capital is the most precious possession of companies in modern economy; therefore, Intellectual Capital of industrial centers is ever-increasingly changing to become the chief indicators both in company operations and in improving its ability to manage the organization capitals. In the main, the current study aims to investigate the relationship between the Intellectual Capital and performance measurement. In this research, the independent variable is the intellectual capital having three dimensions of human, structure and physical capitals, and the dependent variable is the organization operation with two dimensions of economical and accounting which are going to be assessed in this study. The Statistical population is the pharmaceutical companies admitted in the Tehran Stock Exchange from 1387 to 1391 amounting to 30 companies in total. This research investigates the time span from the beginning of 1387 up to the end of year, 1391. Data relevant to variables has been collected by the software of the Stock Exchange. The collection of data has been carried out by means of SPSS. In this study, the researcher used the descriptive and inferential statistics (Spearman test) and the results show that the hypotheses are as follows 1. There is statistical significance between intellectual capital and performance measurement, 2. There is no statistical significance between the intellectual capital and ROR of the owners' salary, 3. There is no statistical significance between the intellectual capital and the ROR of the properties, 4. There is statistical significance between the intellectual capital and the value added of the market, 5. There statistical significance between the intellectual capital and economic value added.
\end{abstract}

Keywords: the intellectual capital, the human capital, structure capital, physical capital, performance measurement, economical assessment, accounting assessment 


\section{Introduction}

$\mathrm{T}$ he organizations are entering the economy based on knowledge. In this economy, knowledge and intangible asset are the most important and competitive advantages of organizations. One part of this intangible asset is the intellectual capital which play a key role on performanceand application of strategies; in this respect, the measurement and the intellectual capital management is vital and is conducive to the observation of the real value of organizations.

In accountancy, the reporting of intellectual capital and its management is fairly necessary for the assessment, management of performance, the decision of the investors and reporting of the performance to beneficiaries. In knowledgebased economy, the success of organizations is dependent on the intellectual capital management.

Intellectual capital is the most precious possession of any company in the modern economy, and soIntellectualCapital of industrial centers is ever-increasingly changing to become the chief indicators both in companies' performance and in improving its ability to manage the organization capitals.

\section{Statement of the Problem}

We are entering knowledge-based society in which the primary economical capitals are not natural resources and the work force anymore. In other words, the chief economical source is knowledge and twenty first century is knowledge-based economy. Before the appearance of knowledge-based economy, industrial economy was the ruling one in which the indicators such as the production of wealth, physical properties like land, work force, money and the machinery were producer of the economical wealth and with the combination of all the aforementioned indicators wealth was produced. In this economy, the use of knowledge had played a very weak role on the production but in the knowledge-based economy, the intellectual capital as one of the indicators of wealth production has more priority over the tangible assets. The intellectual capitals, in particular, the human capitals are one of the most important properties of the organization and the potential success of the organizations is basically rooted in their mental capacity rather than the tangible asset. (Goldi, 1381, 105)

In the past few decades, the trade and the organization has realized the importance of the intangible asset, the development of the marks, the relationships between the shareholders, fame; alongside these, the culture in the organization are considered to be the most important of the stable advantage. In this economy, the ability to create and to use values of these intangible assetsare the chief necessity for the organizations. (King Hung. 2009, 10)

Pulic in the 1998 and 2008 put forward the value added of the intellectual capital for the measurement of the intellectual capital. In this model put forward by Pulic, the intellectual capital has been defined in three different sections of human capital, structural capital and the physical capital. In this research, Pulic model has been used to measure and calculate the intellectual capital as the independent variable. The intellectual capital includes that part of the whole investment of the company or of its property that is knowledge-based and the company as the owner; therefore, the definition of the intellectual capital can also consists of both knowledge (which has turned into the intellectual ownership or the intellectual property of a company) and the final outcome of conveying that knowledge. The legal definition of intellectual property includes only cases such as right of the ownership of things like the patent for invention, the trademark and publications. Pulic in his model has divided the intellectual capital into three parts that interacts in order to work together which are the human capital, the structural capital and the physical capital. (Pulic, 2002, 19)

- The human capital is defined as the abilities, skills and the expertise of the work force. The human capital is capable of thinking. The primary objective of the human capital is the innovation in products, service and the improvements 
in the trading procedures. In this definition, the human capital has been considered to be the total salary expense and the payment of the company. (Pulic, 2002, 14)

- The structural capital consists of the capacities to understand the demands of the market and it also includes cases like the rights of inventions and the established knowledge in organizations process and the organizational culture, the structural capital is the knowledge that remains at the end of work day and it certainly belongs to the whole organization. It can be produced again and it can also be shared. (Pulic, 2002, 14)

- The physical capital is comprised of the stable properties that are used to create the value added in goods and services. According to this definition, the physical capital includes the total properties subtracted by intangible properties. (Pulic, 2002, 15)

\section{The literature Review}

ShahlaEbrahimi in her M. Sc. thesis (1388) investigated the effect of the intellectual capital on the current and future fiscal performanceof the companies. Two hypotheses exist in this research: 1. there is statistical significance between the intellectual capital and the current fiscal performance of the companies in Tehran Stock Exchange. 2. There is statistical significance between the intellectual capital and the future financial performance in Tehran Stock Exchange. Results show that there isstatistical significance between the intellectual capital and the current and the future financial performance of a company in both all companies and the industry but there is negative proportional relationship between the size of the company and the current and future performance of a company.

Zarif far and Nazemi in their study under the title of "analysis of the role of accounting profit and the cash flow in companies in Tehran Stock Exchange" investigates the role of the accounting profit and the cash flow in the assessment of companies in Tehran Stock Exchange. In this study, the researcher has used return on equity as a standard for comparison in order to study and compare the accounting profit and the cash flow. The results of testing these variables is indicative of the fact that the accounting profit has more strong proportional relationship to return on equity in comparison to the cash flow, and as a result the accounting profit has more effecton assessment of the company. In addition, the findings of this research have shown that the size of the companies can influence the profit relations and the cash flow with return on equity. In other words, rising in the size of the companies reduces the profit in proportion to the cash flow in return on equity. However, the kind of industry does not have such a strong effect on the variable of cash and commitment. ( Zarif far and Nazemi, 1383, 94)

Bontis and his Greek colleagues (2004) have carried out research in software companies of Greece focused on the intellectual capital and the organizational performance and unfortunately their results has not been reported owing to lack of the suitable data to measure the intellectual capitals. (Bontis, 2004)

In another research conducted by Bozbura in Turkish industry these results has been obtained that both human capital and customer capital has positive effect on the market value of the companies. ( Bozbura, 2004, 365)

Williams (2000) has used a group of manifesting methods of intellectual capital in annual reporting from FTSE 100 in order to prepare a list of companies from1996 to 2000. In this research he investigated the relationship between the performance of the intellectual capital and the approaches to manifest intellectual capital. Considering the fact that the first aim of this research has been achieved, according to the reported results obtained in comparison to the annual results, this research has shown an increase in manifesting the intellectual capital in annual reports of the public joint- stock companies in Great Britain in FTSE 100. In connection to the second goal of this research, results indicate that if the performance of the intellectual capital is high, manifesting will be reduced.

Rado (2002) has put forward financial approaches to measure the intangible indicators and the intellectual capital in a study titled "the financial methods in measurement of the 
intangible assets". This paper is one of the most important essays in the area of the intellectual capital and is used as the guideline by other researchers.

Belkoue (2003) has published essays under titles of the intellectual capital and the performance of the multinational companies in America. He has investigated the relationship between the return on asset based on the pure value added and the intellectual capital of multinational companies. The result of this research is illustrative of the strong and positive relationship among the variables.

Meritum project: this project has been financed in 2000 by European Hamad. the aim of this project was to offer pieces of advice on the measurement and management of theintellectual capital in order to improve the quality of decisions for the managers and the shareholders. (Bernan, 2000, 8)

In 2005, a similar project to Malaysian one was conducted in Taiwan and in its IT industry. In this project the relationship between the intellectual capital and the performance and a series of scientific models has been analyzed, and consequently confirmed the results of the Malaysian project.

Numerous studies has been carried out by Organization for Economic Co-operation and development since 1982 in intellectual capital areas and in European countries like Holland, Norway, Sweden, Denmark and Ireland a lot of research has been undertaken. (Kenan, 2004, 60)

\section{Conceptual Model of Research}

The diagram 1 shows the variables and the relationships between them in the research:

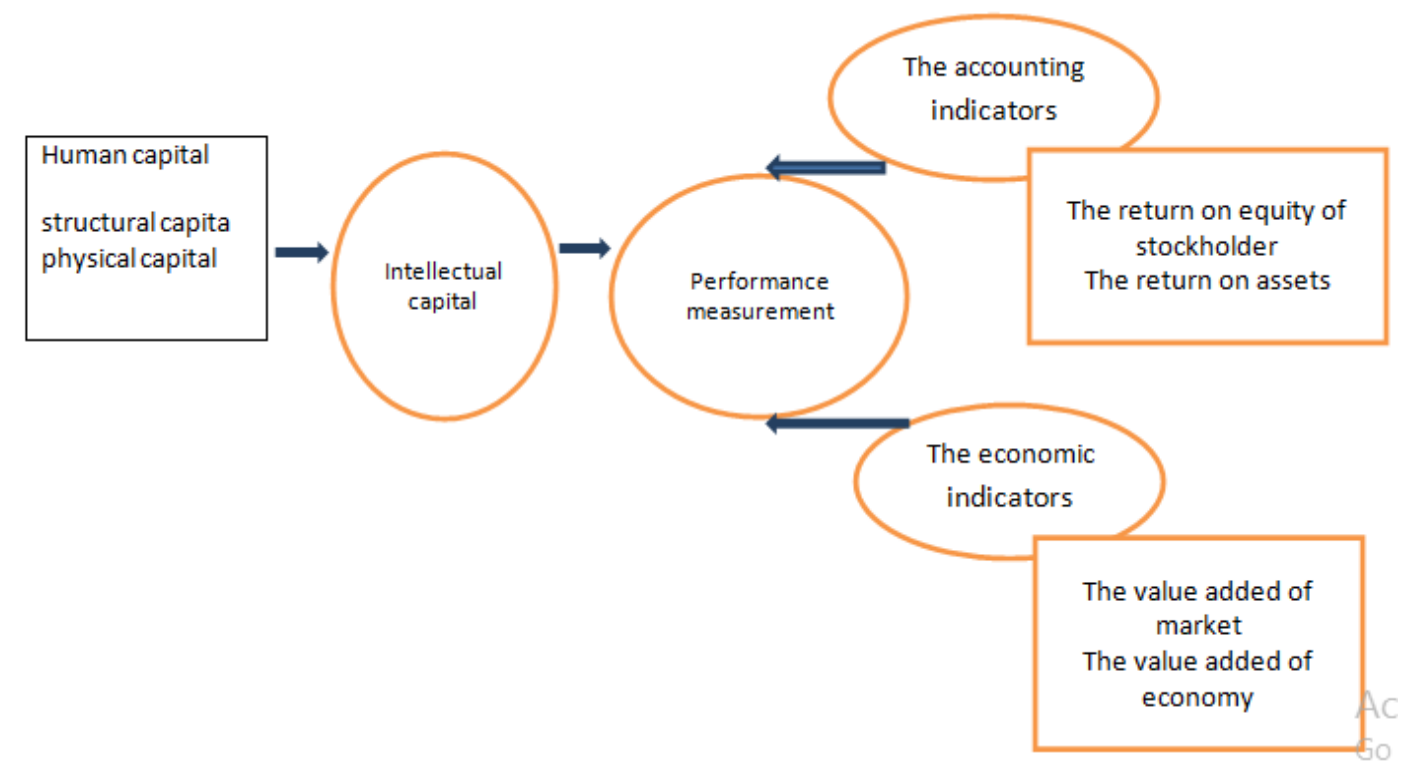

\section{The Hypotheses of the research}

The main hypothesis:

There is statistical significancebetween the intellectual capital and the performance measurement The subsidiary hypothesis

1. There is statistical significance between the return on equity of stockholders and the intellectual capital

2. There is statistical significance between intellectual capital and the return on assets

3. There is statistical significance between the value added of the market and the intellectual capital
4. There is statistical significance between the value added of economy and the intellectual capital

\section{Approach of Research}

To collect data and the information in this research, two methods of library research method and field method has been used. A library research method is the usage of the written information in the library. In this method, researcher has used the documents, evidences, essays, books, journals and theses relevant to the topic of the research, in particular, in second chapter of the research which is the literature review. By and large, in this research 
the field method has been used to gather the necessary data from the stock CDs that are accessible in stock and by means of the companies' fiscal information in the stock market.

\section{The statistic population}

The statistic population is the pharmaceutical companies in Tehran Stock Market from 1387 to 1391 that adds up to 30 in total.

\section{Variable of the Research and method of} measurement

Puilc model was made between the year 1998 and 2000. This model put emphasis on value company on the basis of effectiveness of managing sources in the company. The formula for calculating the co-efficiency of the value added is:

$$
V I A C_{i}^{T M}=H C E_{i}+S C E_{i}+C E E_{i}
$$

In which

VAIC $i=$ the co-efficiency of the value added of intellectual capital of company $i$

$\mathrm{HCEi}=$ the co-efficiency of the human capital of company $\mathrm{i}$

$\mathrm{SCEi}=$ the co-efficiency of the structural capital of company $\mathrm{i}$

$\mathrm{CEEi}=$ the co-efficiency of the physical capital of company $i$

Each variable of this model can be calculated using this formula:

$$
\begin{aligned}
& C E E_{i}=\frac{V A}{C E} \\
& S C E_{i}=\frac{S C}{V A} \\
& H C E_{i}=\frac{V A}{H C} \\
& V_{A i}=P_{i}+I_{i}+C_{i}+D_{i}+D I V_{i}+T_{i}
\end{aligned}
$$

$\mathrm{SC}=\mathrm{VAi}-\mathrm{HCi}$

HC: salary expense and payment

CEi: the value of total properties - the value of the intangible assets

In which:

Ci: salary expense and the payment Ii: rate expense

Pi: profit of company

Ti: tax

DIV: dividends

Di: betterment expense
The intellectual capital and the intangible assets can complement the physical properties immediately. The intellectual capital is the total capital or the right on knowledge which belongs to a company. (Dizonkeski, Romanolha, 2000, 3236).

The dependent variable is the operation of companies in this research. The indicators of performance measurement can be analyzed in light of accounting and economics notions.

In accounting indicators, the performanceof company can be assessed on the basis of the accounting data and is divided in two groups. The first group is the accounting information and the second one is based on both accounting information and the market one.

In economic indicators, the performance of the company has been investigated in regard to the power of making profit out of the existing properties and the potential investment in light of return on equity and the expense of capital.

The indicators based on the accounting information mainly measure the performance of the company by means of the historical information existed in basicfinancial statements and the notes. Theseindicators includes profit, profit of each share, rate of interest rise, the division of the profit, free cash flow, rate of return on equity and rate of return on assets. In this research, only the rate of return on equity and rate of return on assets has been investigated. (Ahmadpor and et al, 1383, 89-91) The rate of return on equity is one of the financial variables that can be achieved by dividing the gross profit by the total book value of stockholder.

Salary of the stockholders/ the gross profit= the rate of return on equity.

The rate of return on assets is one of the financial variables that can be calculated by dividing the net profit by the total properties. (Ahmadpor and et al, 1383, 89-91)

Total properties/ the net profit= ROR on assets

The economic indicators can evaluate the performance of the company in respect to the power of making profits out of existing properties and the potential investments in light of return on equity and capital expense.

The most important indicators in performance measurement that employs the economic indicators are: (Ahmadpor and et al, 1383, 89-91) Market value added 
Economic value added

Salary of stockholder-value of stock

market $=$ market value added

Salary of stockholder-(stock price) (number of issued shares $)=$ market value added

Capital $\times$ ( real rate of return- expected rate of return)=economic value added

In this model:

Salary of stockholders+ current portion of long term debts+ long term debts=used capital

In this formula, net book value of asset has been employed to calculate the capital expense.

\section{The descriptive statistics}

It is necessary to describe the data before the analysis the statistical data in order to grasp the society under study and to get familiar with the research variables. In addition, the statistical description of data is necessary to step to be taken to identify the controlling pattern and to establish foundation to formulize the relations between the variables used in this research. (Khorshidi, Ghoreishi, 1381, 254)

Therefore, the variables are summarized in chart below before testing the hypotheses in this research. This chart consists of Indices for the description of the research variables. These indices are of center, dispersion and indices of distribution shape.

Table 1. Descriptive indices of independent variables

\begin{tabular}{|l|l|l|l|}
\hline Indices, variables & Structural capital & Human capital & Physical capital \\
\hline Amount of data & 120 & 120 & 120 \\
\hline Number of missing & 0 & 0 & 0 \\
\hline average & 461112.63 & 90348790.33 & 5.91 \\
\hline Median & 298349.30 & 11903667.58 & 1.40 \\
\hline Mode & -297.80 & 2863.48 & 60068164.80 \\
\hline Standard deviation & 515375.10 & 2.49 & 1.92 \\
\hline Variance & 2.65 & 6.23 & 3.70 \\
\hline Skewness & 2.75 & 4.75 & 7.83 \\
\hline Error deviation of skewness & .221 & .221 & .221 \\
\hline Kurtosis & 9.68 & 23.84 & 71.14 \\
\hline Error deviation of Kurtosis & .438 & .438 & .438 \\
\hline range & 3047057.98 & 1.64 & 1.89 \\
\hline
\end{tabular}

This chart shows the average of data and the median is indicative of the fact that $\% 50$ of data less than median signifies the symmetry of data. Standard deviation shows the dispersion and finally the skewness is symmetry indicator of data. If the amount of skewness is more than $0 / 05$, this signifies lack of symmetry of distribution. This chart shows the lack of symmetry in distribution. This chart shows the characteristics of the research variables. With all these explanation, it can be concluded that the amount of median in variable (physical capital) is less than average and therefore the skewness is toward right. The standard deviation showing the amount of dispersion is illustrative of the fact that dispersion in structural capital is less than the other capitals, and at last because the amount of skewness is less than 0/05 in variables, distribution of data is symmetrical. 
Table 2. Descriptive indexes of dependent variables

\begin{tabular}{|c|c|c|c|c|}
\hline Indices, variables & $\begin{array}{c}\text { ROR of on } \\
\text { equity }\end{array}$ & ROA & $\begin{array}{c}\text { Value Added of } \\
\text { Market }\end{array}$ & $\begin{array}{c}\text { Economic Value } \\
\text { added }\end{array}$ \\
\hline Amount of data & 120 & 120 & 120 & 120 \\
\hline Number of missing & 0 & 0 & 0 & 0 \\
\hline Average & 55.23 & .55 & 7.91 & 28468.36 \\
\hline Median & 51.94 & .51 & 5.09 & 14386.76 \\
\hline Mode & -20.53 & -.20 & -26849.00 & .000 \\
\hline Standard deviation & 40.94 & .40 & 8.46 & 43157.03 \\
\hline Variance & 1676.67 & .16 & 7.17 & 1.86 \\
\hline Skewness & 3.11 & 3.11 & 2.741 & .22 \\
\hline $\begin{array}{c}\text { Error deviation of } \\
\text { skewness }\end{array}$ & .22 & .22 & .22 & 9.98 \\
\hline Kurtosis & 13.58 & 13. & 9.81 & .43 \\
\hline $\begin{array}{c}\text { Error deviation of } \\
\text { Kurtosis }\end{array}$ & .43 & .43 & .438 & 260687.79 \\
\hline range & 265.14 & 2.65 & 5.01 & .21 \\
\hline
\end{tabular}

This chart shows the average of data and the median is indicative of the fact that $\% 50$ of data which is less than median signifies symmetry of data. Standard deviation shows the dispersion and finally the skewness is symmetry indicator of data. If the amount of skewness is more than $0 / 05$, this signifies lack of symmetry of distribution. This chart shows the lack of symmetry in distribution. This chart shows characteristics of the research variables. With all these explanation, it can be concluded that the amount of median in variable (ROA) is less than average and therefore the skewness is toward right. The standard deviation showing the amount of dispersion is illustrative of the fact that dispersion in economic value added is less than the others, and at last because the amount of skewness is more than 0/05 in variables, distribution of data is asymmetrical.

\section{Inferential Statistics}

Test of subsidiary hypothesis 1 :

There is statistical significance between intellectual capital and ROR on equity.

In the first phase, the relationship between intellectual capital and ROR on equity will be investigated to analyze the hypotheses. If Spearman correlation coefficient between physical capital and ROR on equity is more than 0/05 at the confidence level of 95 percent at least, statistical hypothesis $H_{\circ}$ will be rejected and hypothesis $H_{1}$ will be accepted at the confidence level of 95 at least.

Table 3. correlation coefficient and level of significance Spearman from the subsidiary hypothesis 1

\begin{tabular}{|c|c|}
\hline Intellectual capital & ROR on equity \\
\hline $\begin{array}{c}\text { Spearman correlation } \\
\text { coefficient }\end{array}$ & $-0 / 050$ \\
\hline Level of significance & $0 / 591$ \\
\hline The amount of data & 120 \\
\hline
\end{tabular}

This table puts forward the correlation coefficient, level of significance and the amount of data in a row. Given this, Spearman correlation coefficient between two variables of intellectual capital and ROR on equity is $-0 / 050$. This number shows the relationship between two variables at error level of 0/05. Regarding outputs of SPSS software (table), because Sig is more than $0 / 05$, hypothesis $H_{\mathrm{o}}$ is acceptable at error level of $0 / 05$ and the relationship between these two variables will be rejected.

Test of subsidiary hypothesis 2 :

There is statistical significance between intellectual capital and ROR on assets.

There is no correlational significance between intellectual capital and ROR on asset.

In the first step, the relationship between intellectual capital and ROR on asset will be investigated to analyze the hypotheses. If Spearman correlation coefficient between 
physical capital and ROR on asset is more than 0/05 at the confidence level of 95 percent at least,

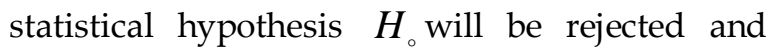
hypothesis $H_{1}$ will be accepted at the confidence level of 95 at least.

Table 4. correlation coefficient and level of significance Spearman from the subsidiary hypothesis 2

\begin{tabular}{|c|c|}
\hline $\begin{array}{c}\text { Intellectual capital } \\
\text { Spearman } \\
\text { correlation coefficient }\end{array}$ & ROR on asset \\
\hline Level of significance & $0 / 591$ \\
\hline The amount of data & 120 \\
\hline
\end{tabular}

The above table puts forward the correlation coefficient, level of significance and the amount of data in a row. Given this, Spearman correlation coefficient between two variables of intellectual capital and ROR on asset is -0/050. This number shows the relationship between two variables at error level of 0/05. Regarding outputs of SPSS software (table), because Sig is more than $0 / 05$, hypothesis $H_{\circ}$ is acceptable at error level of $0 / 05$ and the relationship between these two variables will be rejected.

Test of subsidiary hypothesis 3:

There is statistical significance between intellectual capital and value added of market.

In the first step, the relationship between intellectual capital and added value of market will be investigated to analyze the hypotheses. If Spearman correlation coefficient between intellectual capital and added value of market is more than $0 / 05$ at the confidence level of 95 percent at least, statistical hypothesis $H$ 。 will be rejected and hypothesis $H_{1}$ will be accepted at the confidence level of 95 at least.

Table 5. correlation coefficient and level of significance Spearman from the subsidiary hypothesis 3

\begin{tabular}{|c|c|}
\hline Intellectual capital & $\begin{array}{c}\text { The value added of } \\
\text { market }\end{array}$ \\
\hline $\begin{array}{c}\text { Spearman correlation } \\
\text { coefficient }\end{array}$ & $0 / 857$ \\
\hline Level of significance & $0 / 000$ \\
\hline The amount of data & 120 \\
\hline
\end{tabular}

The above table puts forward the correlation coefficient, level of significance and the amount of data in a row. Given this, Spearman correlation coefficient between two variables of intellectual capital and added value of market is $0 / 857$. This number shows the relationship between two variables at error level of 0/05. Regarding outputs of SPSS software (table), because Sig is less than 0/05, hypothesis $H_{\mathrm{o}}$ is rejected at error level of $0 / 05$ and the relationship between these two variables will be accepted.

Test of subsidiary hypothesis 4 :

There is statistical significance between intellectual capital and economic value added.

In the first step, the relationship between intellectual capital and economic added value will be investigated to analyze the hypotheses. If Spearman correlation coefficient between intellectual capital and economic added value is more than $0 / 05$ at the confidence level of 95 percent at least, statistical hypothesis $H_{\text {。 }}$ will be rejected and hypothesis $H_{1}$ will be accepted at the confidence level of 95 at least.

Table 6. correlation coefficient and level of significance Spearman from the subsidiary hypothesis 4

\begin{tabular}{|c|c|}
\hline Intellectual capital & Economic value added \\
\hline $\begin{array}{c}\text { Spearman correlation } \\
\text { coefficient }\end{array}$ & $0 / 596$ \\
\hline Level of significance & $0 / 000$ \\
\hline The amount of data & 120 \\
\hline
\end{tabular}

The above table puts forward the correlation coefficient, level of significance and the amount of data in a row. Given this, Spearman correlation coefficient between two variables of intellectual capital and added value of market is 0/596. This number shows the relationship between two variables at error level of 0/05. Regarding outputs of SPSS software (table), because Sig is less than 0/05, hypothesis $H_{\circ}$ is rejected at error level of $0 / 05$ and the relationship between these two variables will be accepted.

Test of the main hypothesis:

There is statistical significance between intellectual capital and performance measurement.

In the first step, the relationship between intellectual capital and performance measurement will be investigated to analyze the 
hypotheses. If Spearman correlation coefficient between intellectual capital and performance measurement is more than $0 / 05$ at the confidence level of 95 percent at least, statistical hypothesis $H_{\circ}$ will be rejected and hypothesis $H_{1}$ will be accepted at the confidence level of 95 at least.

Table 7. correlation coefficient and level of significance Spearman of the main hy pothesis

\begin{tabular}{|c|c|}
\hline Intellectual capital & $\begin{array}{c}\text { performance } \\
\text { measurement }\end{array}$ \\
\hline $\begin{array}{c}\text { Spearman } \\
\text { correlation coefficient }\end{array}$ & $0 / 857$ \\
\hline Level of significance & $0 / 000$ \\
\hline The amount of data & 120 \\
\hline
\end{tabular}

The above table puts forward the correlation coefficient, level of significance and the amount of data in a row. Given this, Spearman correlation coefficient between two variables of intellectual capital and added value of market is $0 / 857$. This number shows the relationship between two variables at error level of 0/05. Regarding outputs of SPSS software (table), because Sig is less than 0/05, hypothesis $H_{\mathrm{o}}$ is rejected at error level of 0/05 and the relationship between these two variables will be accepted.

\section{General conclusion of the Research}

There is statistical significance between the intellectual capital and the performance measurement The Spearman correlation coefficient between two variables of intellectual capital and the performance measurementis $0 / 857$. This number shows the relationship between two variables at error level of 0/05, and because the Sig is less than 0/05, the relationship between two variables is acceptable.

In 2005, a similar project to Malaysian one was conducted and in IT industry in Taiwan. In this project the relationship between the intellectual capital and the performance and a series of scientific models has been analyzed, and consequently confirmed the results of the Malaysian project. (Wang, 2005, 230)

The test of subsidiary hypothesis 1 :

There is statistical significance between the intellectual capital and ROR on equity.

Spearman correlation coefficient between two variables of intellectual capital and ROR on equity is $-0 / 05$. This number shows the relationship between two variables at error level of 0/05, and because Sig is more than 0/05, there is no relationship between two variables.

Meritum project: this project has been financed by European Hamad in 2002. The aim of this project was to put forward pieces of advice on the measurement and management of theintellectual capital in order to improve the quality of decisions for the managers and the shareholders. (Bernan, 2000, 8)

Test of subsidiary hypothesis 2 :

There is statistical significance between the intellectual capital and ROR on equity.

Spearman correlation coefficient between two variables of intellectual capital and ROR on equity is $-0 / 05$. This number shows the relationship between two variables at error level of $0 / 05$, and because Sig is more than $0 / 05$, there is no relationship between two variables.

Belkoue (2003) has published essays under title of the intellectual capital and the performance of the multinational companies in America. He investigated the relationship between the return on asset based on the pure value added and the intellectual capital of multinational companies. The result of this research is indicative of the strong and positive relationship among the variables in this research.

Test of subsidiary hypothesis 3 :

There is statistical significance between the intellectual capital and ROR on equity.

Spearman correlation coefficient between two variables of intellectual capital and the market value added is $0 / 857$. This number shows the relationship between two variables at error level of 0/05, and because Sig is less than 0/05, relationship between two variables can be accepted.

Bontis and his Greek colleagues (2004) have carried out research in software companies of Greece by focusing on the intellectual capital and the organizational performance and unfortunately their results has not been reported because of lack of the suitable data to measure the intellectual capitals. (Bontis, 2004)

In another research has been conducted by Bozbura in Turkish industry these results have been obtained: both human capital and customer capital has positive effect on the market value of the companies. (Bozbura, 2004, 365)

Test of subsidiary hypothesis 4 : 
There is statistical significance between the intellectual capital and ROR on equity.

Spearman correlation coefficient between two variables of intellectual capital and the market value added is $0 / 596$. This number shows the relationship between two variables at error level of 0/05, and because Sig is less than 0/05, relationship between two variables can be accepted.

\section{The suggestion based on the research findings}

Some suggestion can be put forward regarding the findings and test of hypothesis in this research:

1. Regarding the future condition of industry and the ever-increasing growing of technology and the customer-orientation of organizations and their internal structure, and based on the findings of the first hypothesis emerged from the correlation power of intellectual capital, the intellectual capital can be used as a indicators for ranking of companies in order to determine their real value in stock market.

2. Regarding the results of the second subsidiary hypothesis stating there is no positive and sematic relationship between intellectual capital and the organization performance, it can be stated that intellectual capital, in particular the structural capital with indicators of ROA and ROR on equity can be employed. In this respect, it can attract the attention of managers and investors to concentrate on internal resources and its abilities in its relationships with clients and to have high level of knowledge and organizational discipline in order to be more ROR.

3. (The main hypothesis) regarding the relationship between the intellectual capital and performance, investors and managers looking for investing in stock exchange can employ this offered model that using the intellectual capital in their model of decision can be conducive to high ROR.

4. Regarding the relationship between the intellectual capital and the value added of the market and the economic value added, the necessity of reflection on such assets in balance sheet is becoming more patent the way that the whole financial information in fiscal forms (such as intellectual capital or physical properties) can lead to determination of the real value of companies by means of accounting system.

\section{Suggestion for the future researches}

The researcher suggests that future researchers rank the existing companies in Tehran Stock Exchange in terms of intellectual capital indicators in order for the investors use aforementioned indicators in their decision model and take heed of efficient allocation of resources.

- It might be suggested that the effect of intellectual capital on risk should be analyzed.

- It might be suggested that the intellectual capital can be measured by means of financial mixed models and non-financial models.

- It can be suggested that the relationship between the intellectual capital and nonfinancial performance such as the client satisfaction, the staff, and the rank in industry, market share and so forth should be investigated.

\section{Refrences}

Alchian, A. A. and Demsetz, H. "Production Information Costs and Economic 
Organization". , American Economic Review, Vol. 62, Issue 5, (1972): 777-795

Anderson R. C and Faust‘G. W(2008 ) Education 'Psychology Bonder, A. (2003). A bluepint for the future: Competency - based management in HRDC. Unpublished presentation, HRDC Cananda.

Bonder, A. (2003). A bluepint for the future: Competency - based management in HRDC. Unpublished presentation, HRDC Cananda

Bontis, N. , 1998, “Intellectual capital: an exploratory study that develops measures and models", Management Decision, Vol. 36 No. 2, pp. 63-76.

Bontis, N. , 2000, , “Assessing knowledge assets: a review of the models used to measure intellectual capital". Available at: www. business. mcmaster. ca, accessed 22 June 2004.

Chen Goh P. , 2005, , “intellectual capital performance of commercial banks in Malaysia", Journal of intellectual Capital, Vol. 6, No. 3, 2005 pp. 385-396, www. emeraldinsight. com /1469-1930. htm,

Chin Chen M. , Ju Cheng S. Hwang Y, , 2005, , "An empirical investigation of the relationship between intellectual capital and firms" market value and financial performance" Journal of intellectual Capital, Vol. 6, No. 2, 2005 pp. 159-176, www. emerald insight. com /1469-1930. htm,

Edvinsson, L. and Sullivan P, (1996). "Developing a Model for Managing Intellectual Capital”, European Management Journal, Vol. 14, No. 4, pp 356-64.

Esterada, 2007, 169-185\& Esterada, 2002b, 365379, Financing Policies and Practices in Large Corporations, pp. 365-379

Estrada, J. 2002a, "Mean-Semi variance Behavior 'II: The D-CAPM ", Finance Letters, March,

Estrada, J. ‘2007, "Mean-Semi variance Behavior: Downside Risk and Capital Asset Pricing ", International Review of Economics and Finance, pp: 169-185.

Fama E. F. , and K. R. French (1998), "Taxes, Financing Decisions, and Firm Value", Journal of Finance, 53 (3);
FamaE. F. , and K. R. French (2004). "Financing Decisions: Who Issues Stock", Journal of FinancialEconomics, 76 (3);

Gupta. O, Roos. G, (2001) "Mergers and acquisitions through an intellectual capital perspective", Journal of Intellectual Capital, Vol. 2 Iss: 3, pp. 297 - 309

Hasbrouck, J. , (2009). "Trading costs and returns for US equities: estimating effective costs from daily data". Journal of Finance 64, 14451477

Jensen M. C. , and W. H. Meckling (1976), "Theory of the Firm: Managerial Behavior, Agency Costs, and Ownership Structure", Journal of Financial Economics, 3 (4);

Johansson. U (1999) Mobilising Change: Characteristics of Intangibles Proposed By 11 Swedish Firms. School Of Business, Stockholm university, P1-31

Kane A. , A. J. Marcus, and R. L. McDonald (1996), "How big are the Tax Advantage to Debt?" Journal of Finance, 39 (3);

Kyle, A. , Vila, J. , (1991). "Noise trading and takeovers. Rand" Journal of Economics 22, 5471

lev, b, ( 1999), "seeing is believing- a better approach to estimate knowledge capital", CFO, 15:29-36

Pulic, A, 2002, "an accounting tool for icmanagement" available at: http://www. measuring-ip. at/papers/ham99txt. html

Pulic, A. 2000. MVA and VAICTM Analysis of randomly Selected Companies from FTSE 250. Austrian Intellectual capital Research center, Graz-London.

Roos, J. Ross, G, Dragonetti, N. C. , Edvinsson, L. (1997), "Intellectual Capital: Navigating in the new business landscape", London: Macmillan press L td.

Stern. B \& steward G, 1989, "The Quest for value: A Guide for senior managers, " New York: huper Bu siness publisher, pp. 316-340

Stern, Joel M. , and John S. Shiely. (2001). "The EVA Challenge: Implementing Value-Added Change in an Organization. " New York: John Wiley \& Sons Inc 
Stewart, T. A. (1997). " Intellectual Capital: the new wealth of Nations", Doubleday Dell Publishing Group, NewYourk, NY.

Sveiby, K. E. , (1985). "The Invisible Balace Sheet, English Translation of the Book Osynliga Balancsrakingen". Available on line: http://www. sveiby. com 